\title{
INNOVATIVENESS AS A RESOURCE FOR THE DEVELOPMENT OF A PERIPHERAL REGION
}

\author{
Arkadiusz TUZIAK \\ University of Rzeszów, Institute of Social Sciences, Poland; atuziak@tlen.pl, ORCID: 0000-0003-3984-4318
}

Purpose: The main goal of the article is to show the role of innovativeness in the context of the development of a peripheral region, with particular emphasis on the analysis of the perception of selected spheres of endogenous development resources by representatives of the regional innovativeness system representing public administration, research and development institutions and enterprises.

Design/methodology/approach: The article uses both the method of analyzing the literature on the subject and the analysis of the results of own sociological research carried out in the Podkarpackie Province under the research grant.

Findings: The analysis of the results of own empirical research carried out in the article shows that the Podkarpackie Province has a significant endogenous development resource located in the sphere of social awareness and positive attitudes of the surveyed inhabitants towards changes and innovativeness $\mathrm{s}$.

Research limitations/implications: Further research on the role of innovativeness in the development of the peripheral region should be focused on in-depth recognition of the innovative personality elements of the inhabitants of the region and their perception of opportunities for using the internal development potential.

Practical implications: The practical implications consist in an attempt to indicate that there is a possibility of a region recovering from the peripheral and marginalized state by using the endogenous development potential of the innovative attitudes and awareness of the regional community.

Social implications: Increasing the scope and level of acceptance of changes and innovative solutions by the regional community, and thus facilitating and accelerating the development and modernization processes in the region.

Originality/value: The value of the article lies in the recognition and analysis of the social dimension of endogenous development resources expressed in the attitudes and innovative awareness of selected categories of inhabitants of the region.

Keywords: Innovativeness, development, peripheral region.

Category of the paper: Research paper. 


\section{Introduction}

Modern socio-economic development is characterized by an increase in the process of territorialisation (Zaucha, and Szlachta, 2015; Nowakowska, 2017, pp. 26-38). On the one hand, dynamic growth clusters are being created, and on the other, there are peripheral regions at risk of marginalization which are taking on development challenges and becoming involved in competitive competition. There are several reasons for territorial disparities in development. This is due, inter alia, to the different, in terms of efficiency, capacity of regions to create a favourable climate for the creation and functioning of innovative enterprises and their institutional and scientific research environment. The variation in the pace of the first degree of progress of development processes at regional level is also a consequence of the increasing role of links within the territorial production systems, the size and quality of human and social capital (Tuziak, 2009, p. 87). It is also largely due to the historical development routes of the various regions of the country (Jałowiecki et al., 2007, pp. 115-132).

The problem of peripheral and development diversification is linked to the fact that each economic system has greater or lesser regional disparities, including asymmetries in the centerperiphery system. It is very important to identify the geographical, organizational and institutional distances between them and the other regions. The geographical distance is analyzed from a physical distance perspective which depends on the existence of natural handicaps and the existence of barriers and on the development of transport and information infrastructure. The organizational distance is defined as the way in which the production is organized, the organizational relation and the degree of similarity of the organizations. The institutional distance concerns recognized and applied models of principles and standards, as well as the existence of forms of collective action, the dissemination of the concept of cooperation, partnership and trust and the capacity to set up informal institutions. In theoretical views which are abstract from the spatial dimension of the phenomenon of peripheral activity, it is indicated that the region's periphery consists of the following elements: low level of development of infrastructure of infomation society, low human capital skills, weak links within local business networks, low civil society activity, lack of institutional density, poor links between the region and the global environment (Olechnicka, 2004, pp. 54-62).

The Polish regions are characterized by significant differences in the level of socioeconomic development. The regions with the highest competitiveness are Mazowieckie Province, Małopolskie Province, Pomorskie Province, Wielkopolskie Province. Their advantage over other regions of the country is due, among other things, to the high efficiency of the productive sector, the high potential of human resources, the relatively welldeveloped infrastructure, the dynamic growth of agglomerations (Gorzelak, 2007, pp. 14-21). Regions with development problems are the provinces of eastern Poland: Lubelskie Province, Podkarpackie Province, Świętokrzyskie Province, Podlaskie and Warmińsko-Mazurskie 
Province. Factors slowing their development include: inefficient employment structure, low productive agriculture, low levels of service and industry development, poor quality of human resources, low urbanization rates, relatively low foreign capital investments.

The Podkarpackie Province, which is an example of the role and significance of endogenous development factors, is one of the regions which seek to reduce development distances in relation to the rest of the country. It is characterized by a considerable dependence of the economy on agriculture, a very low level of human capital, limited territorial accessibility, low level of infrastructure, as well as income of the population and local government units. The region therefore meets the definition criteria applicable to the peripheral regions (Grosse, 2007, p. 7).

The objective of this article is to characterize and analyze the perception of selected spheres of endogenous development resources by representatives of regional actors - public administration, science, business, and expert institutions - creating a regional innovativeness system geared toward dynamic development of the peripheral region. The analyses and characteristics of regional innovativeness determinants refer to the literature of the subject and, in particular, to part of the quality results of the own research carried out under the MNiSzW grant NN 116367637, Innovativeness in the process of endogenous development of the peripheral region. Social study. The research project was an attempt to apply social knowledge in the process of promoting of widely understood innovativeness as an endogenous development factor for a region classified as a peripheral area. The aim was to identify the internal possibilities for shaping the nature and direction of the socio-economic development of the region. It enabled to diagnose an informed dimension of innovative development, as reflected in the opinions and attitudes of representatives of the regional the innovativeness system.

\section{The role of innovativeness in the endogenous development of the region}

The literature highlights the fact that economic development is heavily influenced by values, cultural patterns, social awareness and attitudes (Hryniewicz, 2004; Harrison, and Huntington, 2003). In order to maintain a high dynamic in development, one should shape individuals' innovative awareness, knowledge, qualifications, openness to change, networks of trust-based relationships and reciprocity as essential elements of social capital. The sociologists stress that in development processes involving the creation of modern and flexible forms of organization in every sphere of social life, susceptibility to change and innovativeness is essential, as an important element of a interconnected set of features consisting of modern and innovative personality (Krzysztofek, and Szczepański, 2002, pp. 39-54; Sztompka, 2005, pp. 85-86). 
The development opportunities of the peripheral regions are increasingly determined by endogenous socio-cultural factors relating, in particular, to the quality of human and social capital and to the quality and density of cooperation networks and the links between actors forming a regional innovativeness system - enterprises, public administration, scientific bodies, institutions of the business environment (Tuziak, 2013). In this context, it is important to support local and regional business leaders, especially those who innovate (technology, organization) in their businesses, disseminate experience and good practice in the region and demonstrate a strong commitment to partnering with other companies, as well as with research and development and market infrastructure institutions.

Social capital is important for the development of the peripheral regions, which include Podkarpackie Province, by improving their competitiveness and innovativeness. It is a sociocultural resource that allows networking of cooperative enterprises and regional institutions. The mobilization of social capital resources is a major acceleration of economic development (Woolcock, 1998, pp. 151-208). The peripheral regions, which are lagging behind, tend to be characterized by a shortage of social capital, and lack of cooperation traditions and, above all, trust between entrepreneurs. Trust as an important element of social capital is conducive to cooperation, a civic commitment to public good, the creation of a dense network of associations and regional institutions, and consequently enables economic growth (Putnam, 1995, pp. 258-276). In the peripheral regions, not only the scarcity of social capital, which is the weakness of cooperation between the various actors and the limited number of regional networks, can be a problem. The quality of social capital and, in particular, its inefficiency in generating innovative economic changes (Grosse, 2007, p. 120) may also be a hindrance and barrier to development. In view of the importance of social capital for regional development, the local authorities should play an important role in its building and strengthening. The best way to do this is to implement programs and projects that require the cooperation of the various regional actors. Networking is carried out both on a formal basis, between different institutions and on an informal basis, between individuals. Both types of cooperation play an important role in innovative development. Public authorities should therefore adequately support not only the establishment of institutional and formal procedures for the development of social networks, but also focus the activities of persons and entities having a significant impact on the pace and direction of regional development.

Innovativeness enables dynamic growth and a strong competitive position for cities and regions. Innovativeness is most fully implemented through regional innovativeness networks. Several factors determine the appropriateness of setting up such networks to activate endogenous development resources (Cook, 2007, pp. 12-13). Firstly, interaction is important: in the interactive model of the innovativeness process, both business and science can have a two-way influence on this process: "push" (push) and "pull" (pull). Small regional companies, as well as users of products, processes and services, can be an increasingly important element of interaction. The second factor is the grouping - experience shows that areas of greatest 
economic growth are networks of companies closely cooperating with one another and with state-owned business support agencies. The third important element of regional innovativeness is the creation of networks within which economic coordination takes place. Their forms are neither clearly hierarchical nor market-based, but rather stimulating reciprocity, exchange and trust, are often used by companies in innovative environments. Fourthly, at regional level, all elements of the innovative economy are important - from basic research to market information. Increasing innovativeness through the creation of innovative systems will lead to inter-regional competition and create an opportunity for sustainable and dynamic development.

\section{Innovativeness and development from the perspective of representatives of the regional innovativeness system}

This part of the article will highlight the issue of regional innovativeness in terms of attitudes and content of awareness of the representatives of institutions and organizations included in the regional innovativeness system. The analysis was based on empirical material obtained through in-depth interviews with business, public authorities, universities, R\&D institutions, business environment institutions, including regional development agencies, science and technology parks, technology transfer centers, financial institutions, and expert and opinion leaders representing consulting and advisory bodies and business associations. The research on innovativeness in the context of the development of the Podkarpackie region was carried out, or was mentioned, within the framework of the ministerial research grant entitled 'Innovativeness in the process of endogenous development of the peripheral region. Social study". A total of 174 interviews were carried out, including 99 in Rzeszów and 25 in Krosno, Przemyśl and Tarnobrzeg. They were treated as representatives of the elite as the basis for the creation of a regional creative class. Respondents represented areas and sectors requiring high-level qualifications, knowledge and education, and their activity and professional activity involved in finding new solutions and creating new values (Tuziak, 2016, pp. 23-41).

Innovativeness is a phenomenon that can be considered as a sphere of social singularity, because it is a manifestation of innovativeness, indifference and uniqueness, often leading to overtaking established thinking and action patterns. In the analysis of innovativeness attitudes and awareness among regional representatives, the innovativeness system can therefore be applied to cognitive theory of social singularity (Gumuła, 2008). This model has several levels. The first one is the level of mental resources, i.e. the sphere of awareness and innovativeness attitudes. The second level - regulatory resources - is about an attitude to novelties and innovative changes and ability and need to recognize them as values, as well as principles and rules that foster innovativeness and entrepreneurship. The third level concerns the interaction within the network of relations and links between entities forming the regional innovativeness 
system. The fourth level refers to the social interest, which in the case of Podkarpackie region, could lead to the need to speed up the process of exiting the region from a peripheral state and marginalization.

Due to the limited framework of the article, selected elements of mental resources, i.e. included in the sphere of awareness and innovativeness attitudes, were identified. Such resources were considered essential for the launch and exploitation of the internal development potential. The focus was therefore on the identification by the examined characteristics of modern and innovative personality and on the assessment of the endogenous development potential of the region.

\section{Perception of the elements of modern and innovative personality}

In the literature on the subject there are characteristics and analyses of personality traits conducive to modern development and creative, innovative activity (Inkeles, 1976; Krzysztofek, and Szczepanski, 2002; Sztompka, 2005). Individuals with a modern personality are characterised by openness to change in the external environment as well as to interact with other people and are ready for new experiences and innovativeness $\mathrm{s}$ in different areas of life. They have their own opinions on many social issues, and at the same time they recognize the right of others to express different views, accepting and valuing their diversity. Innovative personality promotes a more present and future-oriented personality than the past-oriented one. It is dominated by optimistic elements, including the belief that human efforts are effective, that social life is regular and predictable in order to plan, anticipate and formulate future goals. In the hierarchy of values of individuals with modern personality, the high position is education and education in a broad sense, as well as justice and respect for the dignity of the second person (Sztompka, 2005, pp. 85-86).

The need for achievements is characteristic of modern personality. The social dimension of this need increases individual competitiveness, non-conformism and innovativeness and thus contributes to growth and growth. The high level of need to achieve and strive for success is conducive to risk-taking and to developing an attitude of acceptance of innovativeness (Krzysztofek, and Szczepański, 2002, p. 44).

An innovative society is created by creative, active, achievement-oriented individuals, characterized by knowledge, imagination and realism, a sense of autonomy, independence and integrity. In an attempt to determine to what extent the so-called "human factor" sets the dynamics of creative transformation of the regional Community, respondents were asked to provide the mental characteristics of the population of Podkarpackie Province (Tuziak, 2013, pp. 298-301). The evaluations and opinions of the respondents can be summarized in a diagram, the basis for describing the "mental profile" of the inhabitants of Podkarpackie Province is the 
intensity of the features on the continuum: innovativeness - conservatism. The majority of respondents stressed that the people of Podkarpackie Province were open to change and novelties, entrepreneurship, flexibility in thinking and acting. This perception of the dominant characteristics of the Podkarpackie Province population has been reflected in the characteristics of the respondents:

People here are clearly entrepreneurial and open to novelties, for instance because these people who were once conservative for years, which was due to a lack of living conditions, emigrated to the West (...). Now you only need to look at the Podkarpackie Province (...) village, how much it has changed, what beautiful houses there are. We can be a showpiece for regions (...). This shows that these people are entrepreneurial, resourceful and somehow manage one their own. Absolutely (KAP 18).

The inhabitants of Podkarpackie region are certainly open if, for example, we look through the prism of creating companies and companies that go bankrupt. Because it is interrelated. However, lots of these companies have been set up. They are trying to do something. Some become successful, others fail. The achievements of some of them here are very serious, because they have built private companies that are starting to compete on the European market (RIOB 23).

Among the respondents there was some ambivalence in the perception of the characteristics of the inhabitants of Podkarpackie Province, as demonstrated by the combination of traditional and conservative elements, with an emphasis on the characteristics of entrepreneurship and openness to change. It seems that this perspective goes beyond a schematic thinking in opposition terms: conservatism - innovativeness and shows the latter in a slightly different light. In the awareness of the respondents, these seemingly contradictory attitudes were combined into a harmonious whole:

I think that the people of Podkarpackie Province are entrepreneurial, but in terms of political views or social attitudes, it can be said that it is a more traditional, more conservative society (...). At the same time, the residents are also entrepreneurial, (...) for example in the economic sphere, in the field of business, while maintaining traditional views and attitudes, e.g. in the family (...) (RN69).

In part, they are [inhabitants of Podkarpackie Province] modern and entrepreneurial, willing to take even a certain risk, so I think. And, in some way they are conservative and it's probably where it stems from. Entrepreneurship (...) has some economic potential (...), and young people are certainly more open to such changes (...) (RN35).

A number of respondents expressed moderately negative opinions on the characteristics and attitudes of the inhabitants of the region, their attitude toward entrepreneurship, innovative change and innovativeness. It was stressed that conservatism and ossification are often linked to low levels of education: 
I believe that this is a society which, through low educational level, conservatism, by the fact that there are also strong family ties, has limited development capacity, but on the other hand, it is also potential that can be used to develop this society, that is to say, building a more modern society (...) (KOIB 18).

An analysis of the attitudes, values and beliefs examined shows that they have developed the characteristics of modern personality. Most have shown willingness to experience new things, openness to innovativeness and change. They expressed their conviction that creativity, appreciation and acceptance of originality and novelty are important in their lives. According to the majority of people surveyed, the attitude of man to the world should be active and curious. Human beings should learn about the truth in the world, so that, as far as possible, they can influence and control social phenomena. The high openness of the respondents to the changes was accompanied by confidence in self-steering of the individuals and the importance of the future.

\section{Perception of the region's internal development potential}

In order to develop regional innovativeness, it is important to be able to identify and then use endogenous resources and development opportunities. This is the basis for creating a vision for the future. The belief that human activities and creative activity can strategically plan and shape the future is characteristic of an active and innovative society. The optimism and hope of, inter alia, the positive assessment of intra-regional development resources were characteristic of the opinions and assessments of the regional innovativeness system surveyed (Tuziak, 2016, pp. 36-40). Regional human capital resources were considered one of the most important internal development factors. An illustration of this perception of development resources is as follows:

Above all, people, in my opinion, are here the number one resource (...), and it was not so recent that we had people in the WSK Rzeszów who were able to build aircraft, build high-class aircraft engines. Today, this is changing because there are components for the F16 engine, but above all we have this human potential, high-class professionals, who can do literally everything. For centuries, Podkarpackie region has in principle been rich in human resources. (...) this shows the educational success we have achieved in Podkarpackie region. Due to educational issues, a certain level of professional qualifications is very good. As a result, I think this is our main strength. People and people again (RIOB 16). 
The region's potential for demographic growth was recognized as an important endogenous resource in the form of a young and well-educated society:

$A$ very young society is a huge asset. Of what I remember, 50\% of the youth population in the region is already studying today. Even in the old times this was only an eight-percent figure. (...) well-educated staff at Podkarpackie universities are also an asset. (...) Young society, welleducated staff are the assets and opportunities for development in the region (RAP20).

While recognizing human resources as an important development asset in the region, respondents stressed the negative trend of emigration of skilled and educated people. The awareness that human resources are a valuable and declining capital of the region is reflected in the assessments and opinions expressed by respondents:

Looking at young people, unfortunately, it still seems to me that there are not enough jobs for young people and, nevertheless, they are trying to escape from Podkarpackie region (RBR8).

One can see that young people, I think they have gone to England, Ireland or even to the United States. Others, you know, they learn, there are universities, even on a very good level, I sometimes have a contact with the University of Technology, I know that the level is really good. But even as they learn, they receive this diploma, they must seek work in Krakow, Warsaw, etc. (RP15).

According to the respondents, the areas in which significant and still underutilized internal development factors are located are industry and regional raw material resources:

The pharmaceutical, it and food industries are one of the highly developed sectors of the economy. Despite some regression in recent years, the aviation industry is still characteristic of the region. In the southern, more mountainous part, a number of mineral resources are extracted, including: sandstones, limestones, gypsum, ceramic clay, sand, including glasshouse sand and gravel. There are also numerous intakes of mineral water in the south, distributed throughout the country. (...) the main fossil raw materials are sulfur, oil and natural gas. Renewable energy sources, in particular thermal sources, are a great opportunity. (...) The mere existence of investments related to the extraction and processing of raw materials, inter alia, through the creation of new jobs, will contribute to the overall development of the region (TAP12).

Better use of the economic potential of the region was identified by respondents as their main development opportunity. In this context, awareness of the risks associated with the basis of the regional economy in one dominant sector has become apparent:

The economic potential of the province is significant, that is to say, a very good cluster of Aviation Valley. In the region there is close to $90 \%$ of the aviation industry, including all national production (...) this is also a huge asset. But we must remember to diversify this. We cannot just be so heavily dependent on the aviation industry, because if the turbulence we have experienced over the last two years was to happen, it would have a very negative impact on the socio-economic situation of the Podkarpackie Province. We need to attract investors in 
various sectors: automotive, IT, chemical industry. I think there are many industries in which development opportunities are due to the fact that we are very [ecologically] pure province. We need to invest in renewable energy sources, and that is also a great potential. We also have a lot of opportunities to use geothermal waters (...), but I do not know why this sector is not developing (RIOB 72).

Respondents highlighted the high growth potential of the region's environmental value. They often stressed that the development opportunity of Podkarpackie is tourism and the development of related industries using environmental assets, which are clean:

They are natural assets, in the form of Bieszczady and other areas (...), which in future are this expected driver of development (...), if it were to build a solid [tourist] infrastructure, then perhaps Europe would have been dragging to Poland, but it still needs time and money. An asset is a natural location, (...) ecology, because we can enjoy relatively clean air, clean water, uncontaminated with soil, and that is something that can be used in the future (...). Let us follow an example of countries such as Germany and France. They don't have forests because they cut them off a long time ago. We have, let us keep it, let us protect it (...) today in the communication sense we are far behind Europe, but it may change, and sometime we will say: please visit Bieszczady, because there is a natural spruce forest, a beech forest, others no longer have it. This is some chance. As regards environmental asset, I think that this is a matter that we cannot overestimate (...). In the European Union (...) there are no such pearls. We have an asset that we can use (KAP18).

Investment in tourism services, tourism infrastructure and organic food production is, according to the respondents, very beneficial and desirable in terms of regional development. Developing and modernizing the accommodation and catering base, extending the scope and quality of tourism offers is a development strategy for modernizing existing endogenous regional resources. Some respondents preferred this development path. Many realized, however, that a new endogenous resource for the region should be built by diversifying existing activities. This is illustrated by the following statement:

In my opinion, Podkarpackie region, in terms of development resources and opportunities, can mainly generate added value in the form of tourism products, because it has very great tourist value. But I think that is not enough. This cannot be the only thing that Podkarpackie region can show off. Podkarpackie region innovativeness -oriented, at least Rzeszów, Podkarpackie capital, a city of innovativeness. There is also a chance here. Investments which the economic zones of the city and the region can attract can be a driver of development (RN38).

Some respondents to the development opportunities of the region were looking at its border location:

The opportunity for Podkarpackie region is that it is indeed the eastern border of the European Union. At the same time, it is a considerable problem, because Western investors will not want to appear here, but perhaps once Ukraine is aspiring to become a member of the 
European Community in a more obvious way, perhaps this region will become a channel through which trade will take place for the benefit of the region (PN10).

Responders linked the internal potential of Podkarpackie region both with human capital resources and with the development of certain industrial sectors, notably the aerospace, it, chemical and food industries (geared toward organic food production). Development opportunities have also been seen in the tourism industry, cross-border cooperation and better use of raw materials. In the opinions of the respondents, the most development potential is used in high-tech industries, i.e. aerospace, it and chemical industries.

\section{Summary}

Analysis of the attitudes and opinions of representatives of the regional innovativeness system - entrepreneurs, representatives of science, public administration and institutions of the business environment - which form the seeds of the creative class of the region shows that Podkarpackie region has significant endogenous resources. Their effective use improves regional innovativeness and competitiveness. They are primarily located at the social level, in terms of values, attitudes, trust and networks of relations, and of awareness of entrepreneurship and openness to change and innovativeness. The use of mental, normative, interactive resources in combination with the development of innovative and modern personality features is the basis for the regional Community's interest in overcoming development delays and becoming increasingly better in inter-regional competition.

The use of a regional resource of development factors to create a competitive and innovative economy does not necessarily mean a radical break with the past. It may, or should, refer to existing development resources and traditions in the sphere of social and economic activity. An analysis of the attitudes and views of the representatives of the institutions and organizations forming the regional innovativeness system has emerged as a model of regional development, in which two areas of action can be distinguished. The first area involves the innovative development of an already existing resource of development factors linked to traditional regional economic activities. The second sphere is to build a new resource for the endogenous development of the region by supporting high-tech industries - mainly aerospace, electromechanical and it. In order to implement the vision for innovative development of the region, its scientific and research base should be strengthened, cooperation between business and science should be developed. It is also important to improve the efficiency of actions taken by the regional authorities and develop the infrastructure of the business environment. The emigration of educated and active inhabitants of the region must also be prevented, as the outflow of human capital poses a serious risk to the process of building a new regional endogenous resource. 
In the Podkarpackie region, the essential elements of an innovativeness environment which is a whole and which is reflected in specific pro-development attitudes and activities can be identified. A network of regional entities has been developed and strengthened, including public authorities, enterprises, research and research institutions, and the business environment. The innovative environment in the region consists of both tangible elements - enterprises and progressively developed and modernized technical and intangible infrastructure - in terms of knowledge resources, social capital, values, standards, rules and behavioural patterns. The cooperation of regional entities in the innovativeness system makes it possible to make better use of common endogenous development resources.

\section{References}

1. Cooke, P. (2007). Social Capital, Embeddedness, and Regional Innovativeness. In: M. Landabaso, A. Kukliński, C. Roman (eds.), Europe-Reflections on Social Capital, Innovativeness and Regional Development: The Ostuni Consensus. Nowy Sącz: Wyższa Szkoła Biznesu - National Lous University.

2. Gorzelak, G. (2007). Rozwój polskich regionów a polityka spójności Unii Europejskiej. In: G. Gorzelak (ed.), Polska regionalna i lokalna $w$ świetle badań EUROREG-u. Warszawa: Center of European Regional and Local studies, Scholar Scientific Publishing House.

3. Grosse, G.T. (2007). Innovative economy on the periphery? Warsaw: Foundation for the Institute of public Affairs.

4. Gumuła, W. (2008). Teoria osobliwości społecznych. Zaskakująca transformacja w Polsce. Warszawa: Wydawnictwo Naukowe Scholar.

5. Harrison, R., Huntington, S. (eds.) (2003). Kultura ma znaczenie. Jak wartości wpływaja na rozwój społeczeństw. Poznań: Zysk i S-ka.

6. Hryniewicz, J.T. (2004). Polityczny i kulturowy kontekst rozwoju gospodarczego. Warszawa: Wydawnictwo Naukowe Scholar.

7. Inkeles, A. (1976). A model of the modern man: Theoretical and methodological issues. In: C. Black (ed.), Comparative Modernizations. New York: Free Press.

8. Jałowiecki, B., Szczepański, M.S., Gorzelak, G. (2007). Rozwój lokalny i regionalny w perspektywie socjologicznej. Tychy: Śląskie Wydawnictwo Naukowe Wyższej Szkoły Zarządzania i Nauk Społecznych im. Ks. Emila Szramka.

9. Krzysztofek, K., Szczepański, M.S. (2002). Zrozumieć rozwój. Od społeczeństw tradycyjnych do informacyjnych. Katowice: Wydawnictwo Uniwersytetu Śląskiego. 
10. Nowakowska, A. (2017). Terytorializacja rozwoju i polityki regionalnej. Biuletyn KPZK, Komitet Przestrzennego Zagospodarowania Kraju Polskiej Akademii Nauk, Zeszyt 268, pp. 26-38.

11. Olechnicka, A. (2004). Regiony peryferyjne $w$ gospodarce informacyjnej. Warszawa: Wydawnictwo Naukowe Scholar.

12. Putnam, R.D. (1995). Demokracja w działaniu. Tradycje obywatelskie we wspótczesnych Włoszech. Kraków-Warszawa: Wydawnictwo Znak, Fundacja im. S. Batorego.

13. Sztompka, P. (2005). Socjologia zmian społecznych. Kraków: Wydawnictwo Znak.

14. Tuziak, A. (2009). Przejawy aktywności społeczności regionalnej w pokonywaniu dystansów I zróżnicowań rozwojowych. Przypadek region peryferyjnego. In: A. Tuziak, B. Tuziak (eds.), Regionalny wymiar procesów transformacyjnych. Zróżnicowania i podziały. Warszawa: Wydawnictwo Naukowe Scholar.

15. Tuziak, A. (2016). Innowacyjność a rozwój regionu w percepcji rzeszowskich przedstawicieli regionalnego systemu innowacji. In: M. Malikowski, B. Szluz, Problemy społeczno-przestrzenne współczesnego Rzeszowa. Rzeszów, Wydawnictwo Uniwersytetu Rzeszowskiego.

16. Tuziak, A. (2013). Innowacyjność $w$ endogenicznym rozwoju region peryferyjnego. Studium socjologiczne. Warszawa: Wydawnictwo Naukowe Scholar.

17. Woolcock, M. (1998). Social capital and economic development: toward a theoretical synthesis and policy framework. Theory and Society, 1, pp. 151-208.

18. Zaucha, J. Szlachta, J. (2015) (eds.), Terytorialny wymiar wzrostu i rozwoju. Warszawa: Difin, Sopot: Instytut Rozwoju. 